\title{
Cardioprotective Potential of Ethanol Extract of Sonchus Arvensis L. Leaves on Isoproterenol-Induced Myocardial Infarction in Rat
}

\section{(Aktivitas Kardioprotektif Ekstak Etanol Daun Tempuyung (Sonchus arvensis L.) pada Model Hewan Infark Miokardial yang Diinduksi Isoproterenol)}

\author{
NENG FISHERIKURNIATI ${ }^{1 *}$, ELIN YULINAH SUKANDAR ${ }^{1}$, RIAN PARDILAH ${ }^{1}$, NOVA \\ SULISKA ${ }^{1}$, DHYAN KUSUMA AYUNINGTYAS ${ }^{1}$
}

${ }^{1}$ Kelompok Keilmuan Farmakologi-Farmasi-Klinik, Sekolah Farmasi, Institut Teknologi Bandung.

Submitted 20 December 2017, Accepted 9 February 2018

\begin{abstract}
Sonchus arvensis L. leaves has been used traditionally to treat various disease conditions to descrease blood preasure and increase urine excretion. This study was designed to evaluate cardioprotective potential of ethanol extract of $S$. arvensis leaves on isoproterenol-induced myocardial infarction in Wistar rat. Male Wistar albino rats were divided into three main groups: negative control (saline only), positive control (isoproterenol only), and S. arvensis extract treated groups. S. arvensis extract was administered in three doses; 50, 100, and $200 \mathrm{mg} / \mathrm{kg}$ b.w. p.o for 14 days. On day 13 and 14, isoproterenol $(85 \mathrm{mg} / \mathrm{kg} \mathrm{bw})$ was given intraperitoneally to positive control and extract treated groups. The parameters studied were cardiac biomarker enzymes which were Creatine Kinase (CK), Creatine Kinase-MB (CK-MB), Aspartate Transaminase (AST), Alanine Transaminase (ALT) and Lactate Dehydrogenase (LDH). The results showed that $S$. arvensis at dose of $50 \mathrm{mg} / \mathrm{kg}$ b.w. could significantly $(\mathrm{P}<0.05)$ reduce the level of CK, CK-MB, AST, ALT, and LDH in myocardial infarcted rats compared to positive control. The increase of the dose of S. arvensis extract was not followed by an increase of its cardioprotective activity. In conclusion, Sonchus arvensis L. leaves extract at dose of $50 \mathrm{mg} / \mathrm{kg}$ b.w. has potential to be developed as cardioprotective drug.
\end{abstract}

Keywords: Sonchus arvensis L., isoproterenol, myocardial infarction, cardioprotective drug.

\begin{abstract}
Abstrak: Daun Sonchus arvensis L. telah digunakan secara tradisional untuk mengobati berbagai kondisi penyakit termasuk menurunkan tekanan darah dan meningkatkan urinasi. Penelitian ini dirancang untuk mengevaluasi potensi kardioprotektif ekstrak etanol daun Sonchus arvensis L. pada model hewan tikus infark miokardial yang diinduksi dengan isoproterenol. Tikus jantan jenis Wistar dibagi menjadi empat kelompok utama: kontrol negatif(hanya salin), kontrol positif (hanya isoproterenol), kelompok perlakuan ekstrak etanol daun Sonchus arvensis L. diberikan dalam tiga dosis yaitu 50, 100, dan $200 \mathrm{mg} / \mathrm{kg}$ bb p.o selama 14 hari. Pada hari ke 13 dan 14, isoproterenol ( $85 \mathrm{mg} / \mathrm{kg} \mathrm{bb})$ diberikan secara intraperitoneal pada kelompok kontrol positif dan ekstrak. Parameter yang diukur adalah enzim biomarker jantung, yaitu Creatine Kinase (CK), CK-MB, Aspartat Transaminase (AST), Alanine Transaminase (ALT) dan Laktat Dehidrogenase (LDH). Hasil penelitian menunjukkan bahwa ekstrak etanol daun Sonchus arvensis $\mathrm{L}$. pada dosis $50 \mathrm{mg} / \mathrm{kg}$ bb secara signifikan $(\mathrm{P}<0,05)$ menghambat peningkatan kadar $\mathrm{CK}$, CK-MB, AST, ALT, dan LDH pada tikus yang mengalami serangan jantung miokardial dibandingkan dengan kontrol positif. Peningkatan dosis ekstrak $S$. arvensis tidak diikuti dengan peningkatan aktivitas kardioprotektif. Dengan demikian disimpulkan bahwa ekstrak daun Sonchus arvensis L. pada dosis 50 $\mathrm{mg} / \mathrm{kg}$ bb memiliki potensi untuk dikembangkan sebagai obat kardioprotektif.
\end{abstract}

Kata kunci: Sonchus arvensis L., isoproterenol, infark miokardial, obat kardioprotektif.

\footnotetext{
* Correspondence Author, Hp: 085315826154

e-mail: nfkurniati@fa.itb.ac.id
} 


\section{INTRODUCTION}

BASED on World Health Organization, cardiovascular disease is the number one cause of deaths in the world $^{(1)}$. Based on data in 2012 showed 17.5 million people died from cardiovascular disease. Among these, the ischemic heart diseases, acute myocardial infarction (MI) in particular, is one of the most alarming values.

The induction of myocardial infarction in isoproterenol-induced rats is a standard test in preclinical studies of cardioprotective effects that exhibit an influence on metabolic and morphological changes in cardiac tissue as in humans. Isoproterenol [1- (3, 4-dihydroxyphenyl) -2-isopropylamino ethanol hydrochloride] is a sympathomimetic group of drugs with an adrenegic beta-agonist mechanism in which it binds to the $\beta 1$ receptor present in the heart that has the effect of increasing the contraction of the heart muscle ${ }^{(2)}$. Continuous contraction of the heart muscle can cause damage to the heart muscle cells. Isoproterenol induces necrosis in the sub-endocardial region of the left ventricle in the interventricular septum $^{(3)}$. Myocardial infarction can be triggered by the presence of oxidative stress in which isoproterenol is a drug compound that can induce oxidative stress due to the presence of free radicals ${ }^{(4)}$.

Sonchus arvensis L. leaves is a plant derived from Eurasia. It is known to have efficacy as diuretic, anti-inflammation and anti-pyretic. Sonchus arvensis L. contains flavonoid in the form of luteolin, luteolin 7-O glucosida ${ }^{(5)}$, kaempferol, orientin, and quercetin ${ }^{(6)}$. A study showed that quercetin in plants have activity on cardiovascular disease, such as lowering blood pressure $^{(7)}$.

As quercetin has an activity as antioxidant, therefore, Sonchus arvensis L. was suspected to have cardioprotective activity. In this study, cardioprotective activity of Sonchus arvensis L. was conducted on isoproterenol-induced myocardial infarction in rats.

\section{MATERIALS AND METHODS}

MATERIALS. Isoproterenol was obtained from Sigma-Aldrich (MO, USA). Analyzing kits for measuring Creatine Kinase (CK), CK-MB, Aspartate Transaminase (AST), Alanine Transaminase (ALT) and Lactate Dehydrogenase (LDH) were obtained from Sclavo Diagnostic International, Italy. All of other reagents were analytical grades. All parameters were assessed using Microlab 300, ELITech Group, France.
Plant Leaf Collection and Identification Instruments. Sonchus arvensis L. leaves were collected from medicinal plants of PT. Kimia Farma, which is located at Baleendah street, Bandung, West Java. Determination of the plant was done at Herbarium Bandungense Bandung Institute of Technology.

Extraction of the Crude Plant. Preparation of ethanol extract of Sonchus arvencis L. leaves was done using cold extraction method. Five hundred gram of dried plant were inserted into macerator and soaked with $96 \%$ ethanol for 24 hours, liquid extract was then collected. Maceration process was repeated for 3 times. Furthermore, the liquid extract was concentrated using a rotating vacuum, and viscous extract was then dried in the oven at $50{ }^{\circ} \mathrm{C}$.

Experimental Animals. Male Wistar rats (150$200 \mathrm{~g}$ ) were used for the experiment. All animals were obtained from the School of Pharmacy, Bandung Institute of Technology. The animals were acclimatized for 1 week at laboratory conditions before starting the experiment and fed with a standard pellet diet and water ad libitum. All animal experimental protocols have been approved by the Institutional Animal Ethics Committee (IAEC) in accordance with the Committee's guidelines for the Objective of Supervision and Control of Animal Experiments.

Experimental Design. The myocardial infarction was induced in experimental rats by intraperitoneal injection of isoproterenol hydrochloride (ISO) at a dose of $85 \mathrm{mg} / \mathrm{kg}$ body weight for 2 consecutive days.

The rats were randomly divided into five groups with six rats each, as can be seen below:

- Group negative control: This group served as normal control and received normal saline $(5 \mathrm{~mL} / \mathrm{kg}$ b.w. i.p.). - Group positive control (ISO): The rats were orally fed $0.9 \%$ normal saline once daily for 14 days and in addition received ISO $(85 \mathrm{mg} / \mathrm{kg}$ body weight i.p. ) on day 13 and 14 at an interval of $24 \mathrm{~h}$.

- Group extract 50+ISO: The rats were pre-treated with ethanol extract of S. arvensis at dose of $50 \mathrm{mg} /$ $\mathrm{kg}$ b.w. p.o. for a period of 14 days and in addition received ISO ( $85 \mathrm{mg} / \mathrm{kg}$ body weight i.p.) on day 13 and 14 at an interval of $24 \mathrm{~h}$.

- Group extract 100+ISO: The rats were pre-treated with ethanol extract of S. arvensis at dose of $100 \mathrm{mg} /$ $\mathrm{kg}$ b.w. p.o. for a period of 14 days and in addition received ISO $(85 \mathrm{mg} / \mathrm{kg}$ body weight i.p.) on day 13 and 14 at an interval of $24 \mathrm{~h}$.

- Group extract 100+ISO: The rats were pre-treated with ethanol extract of S. arvensis at dose of $200 \mathrm{mg} /$ $\mathrm{kg}$ b.w. p.o. for a period of 14 days and in addition received ISO $(85 \mathrm{mg} / \mathrm{kg}$ body weight i.p. on day 13 and 14 at an interval of $24 \mathrm{~h}$. 
After $24 \mathrm{~h}$ of the last treatment, orbital blood samples were collected from all groups. Serum samples were separated for the estimation of cardiac biomarkers such as Creatine Kinase (CK), CK-MB, Aspartate Transaminase (AST), Alanine Transaminase (ALT) and Lactate Dehydrogenase (LDH).

Statistical Analysis. Significant difference between control and experimental groups was assessed by ANOVA test. $\mathrm{P}<0.05$ was considered to be statistically significant.

\section{RESULTS AND DISCUSSION}

Myocardial infarction (MI) is a death or necrosis of myocardial tissue due to a sudden decrease of blood flow from coronary heart disease and or sudden increase of oxygen demand ${ }^{(8)}$. The present study showed development of oxidative cardiac injury induced by isoproterenol ${ }^{(9)}$ which lead to significant increase in cardiac biomarkers Creatine Kinase (CK), CK-MB, and Lactate Dehydrogenase (LDH) (Table 1).

Table 1. Effect of isoproterenol administration on cardiac biomarker level.

\begin{tabular}{|c|c|c|c|c|c|}
\hline \multirow{3}{*}{ Gloulps } & \multicolumn{5}{|c|}{$\begin{array}{l}\text { biomarker level. } \\
\text { Cardiac biomankerl level }\end{array}$} \\
\hline & $\mathrm{CK}$ & $C \mathrm{CK} \cdot \mathrm{MB}$ & LDH & AST & ALT \\
\hline & $(\operatorname{mig} d \mathrm{~L} L)$ & (II) & (IU) & (IIT) & (II) \\
\hline Negative Group & $0.61 \pm 0.01$ & $81.38 \pm 6.09$ & $20077 \pm 14.57$ & $40.07 \pm 11.66$ & $41.32 \pm 10.08$ \\
\hline Positue Group (ISO) & $1.44 \pm 0.11^{1}$ & $180.77 \pm 7.65^{\mathrm{t}}$ & $501.16 \pm 567.26^{t}$ & $127.56 \pm 10.53^{x}$ & $138.64 \pm 8.60^{2}$ \\
\hline
\end{tabular}

Note: $\overline{\mathrm{CK}}=$ Creatinin Kinase, $\mathrm{CK}-\mathrm{MB}=$ Creatinin Kinase-MB, $\mathrm{LDH}=$ Lactate Dehydrogenase, $\mathrm{AST}=$ Aspartate transaminase, ALT $=$ Alanine transaminase, $*=$ significantly different compared to negative group $(\mathrm{P}<0.05)$.

Creatinin kinase (CK) is an enzyme that is found in high concentrations in heart muscle and skeletal muscle damage. However, creatinine kinase is also present in the lungs, skeletal muscles, and the brain so it is not particularly specific to the heart muscle. Creatinine kinase is a dimeric molecule consisting of a pair of different monomers namely MM, MB, and BB. While CK-MB is a heart muscle biomarker that increases in number if there is damage to the heart muscle $^{(8)}$. Therefore, in myocardial infarction, CK level increase was followed by increasing of CK-MB level.

Lactate dehydrogenase (LDH) is an intracellular enzyme found in almost all metabolized cells. LDH with the highest concentration is found in the heart, skeletal muscle, liver, kidney, brain, and red blood cells. The increase of LDH level in serum suggests an increased of oxygen demand ${ }^{(10)}$. Other conditions that can cause increased LDH serum include hypoxia, tissue injury, and necrosis ${ }^{(11-13)}$.

In this experimental results also showed a significant increase in Aspartate Transaminase (AST) and Alanine Transaminase (ALT) level in the positive group compared to negative group (Table 1). AST and ALT are specific transaminase enzymes present in liver cells, but also in the heart and brain. Although the serum AST and ALT are non-specific presence of heart, but its concentrations increased during MI.

In this study, it showed that administration of $S$. arvensis L. extract at doses of 50,100 and $200 \mathrm{mg} /$ $\mathrm{kg}$ body weight could significantly decrease level of CK (Fig.1), CK-MB (Fig.2), LDH (Fig.3), AST and ALT (Fig. 4) compared to isoproterenol-administration only. However, the dose increase did not affect reduction of those markers. It suggested that the extract effect did not dependent on the dose.

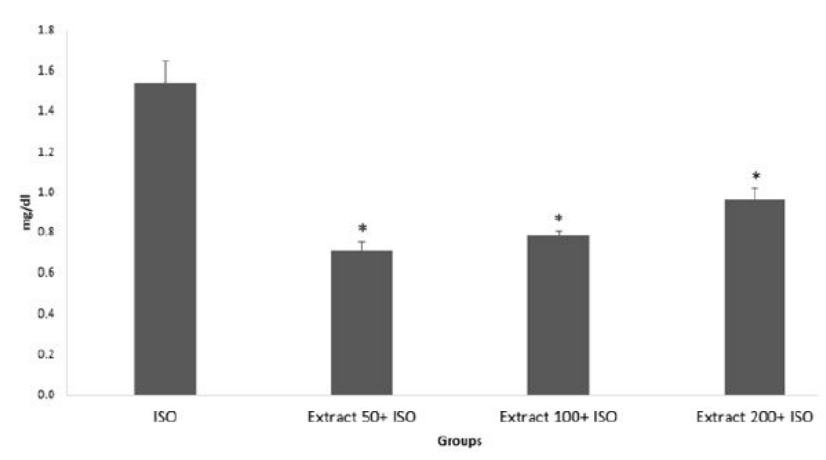

Figure 1. Effect of ethanol extract of $S$. arvensis on creatinin kinase (CK) level in isoproterenol-induced myocardial infarction rats.

ISO $=$ rats were administered only with isoproterenol $(85 \mathrm{mg} /$ $\mathrm{kg} \mathrm{bw})$. Extract $+\mathrm{ISO}=$ rats were administered previously with $S$. arvensis extract at certain doses $(50,100$, or $200 \mathrm{mg} / \mathrm{kg} \mathrm{bw})$ for 14 days before isoproterenol administration. $*=$ significantly different compared to ISO group $(\mathrm{P}<0.05)$.

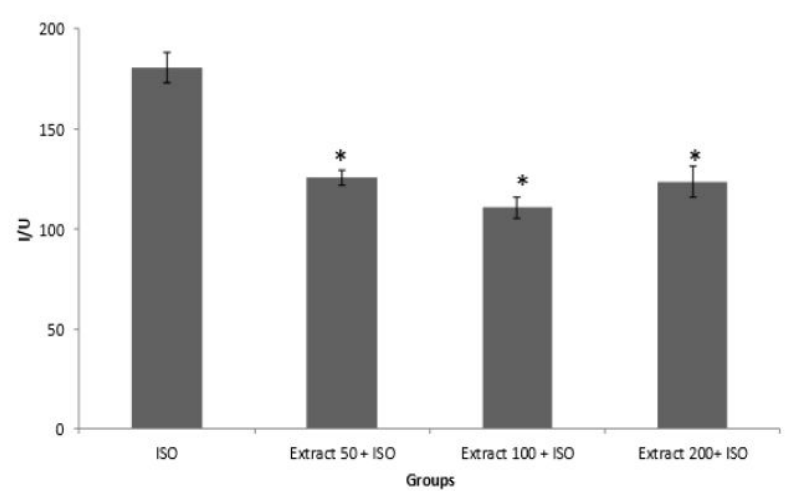

Figure 2. Effect of ethanol extract of $S$. arvensis on creatinin kinase (CK)-MB level in isoproterenol-induced myocardial infarction rats.

$\mathrm{ISO}=$ rats were administered only with isoproterenol $(85 \mathrm{mg} / \mathrm{kg}$ bw). Extract $=$ rats were administered previously with $S$. arvensis extract at certain doses $(50,100$, or $200 \mathrm{mg} / \mathrm{kg} \mathrm{bw})$ for 14 days before isoproterenol administration. ${ }^{*}=$ significantly different 
compared to ISO group $(\mathrm{P}<0.05)$.

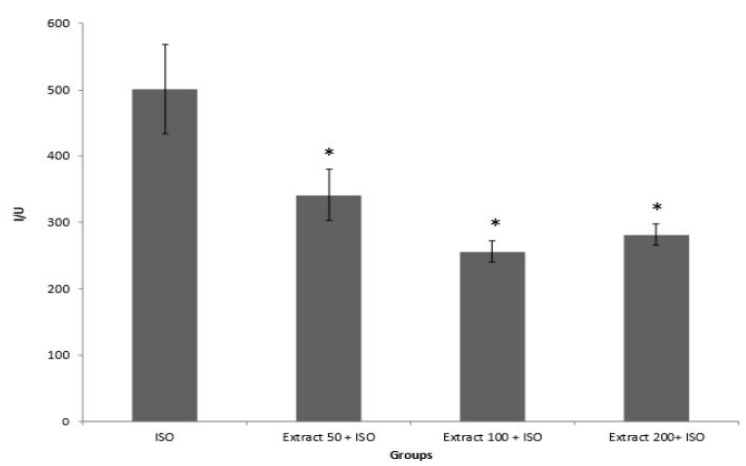

Figure 3. Effect of ethanol extract of $S$. arvensis on lactate dehydrogenase (LDH) level in isoproterenol-induced myocardial infarction rats.

ISO $=$ rats were administered only isoproterenol $(85 \mathrm{mg} / \mathrm{kg} \mathrm{bw})$. Extract $+\mathrm{ISO}=$ rats were administered previously with $S$. arvensis extract at certain doses $(50,100$, or $200 \mathrm{mg} / \mathrm{kg} \mathrm{bw})$ for 14 days before isoproterenol administration. $*=$ significantly different compared to ISO group $(\mathrm{P}<0.05)$.

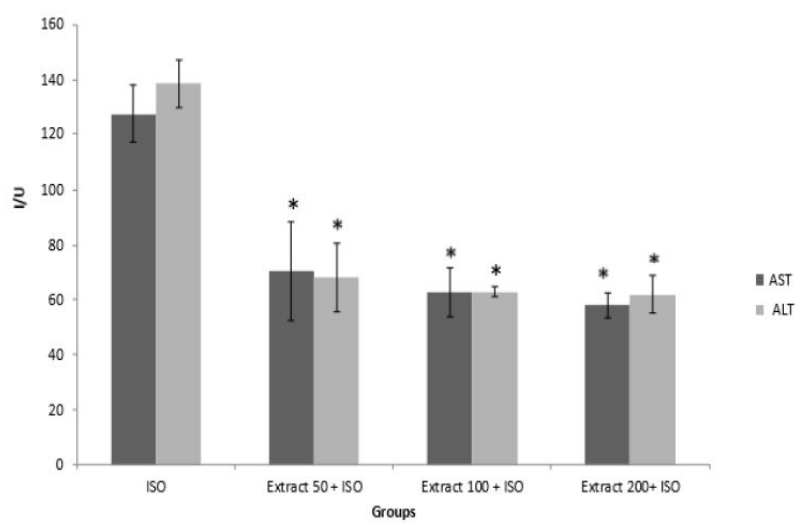

Figure 4. Effect of ethanol extract of $S$. arvensis on aspartate transaminase (AST) and alanine transaminase (ALT) level in isoproterenol-induced myocardial infarction rats.

ISO $=$ rats were administered only with isoproterenol $(85 \mathrm{mg} / \mathrm{kg}$ bw). Extract + ISO = rats were administered previously with $S$. arvensis extract at certain doses $(50,100$, or $200 \mathrm{mg} / \mathrm{kg} \mathrm{bw})$ for 14 days before isoproterenol administration. $*=$ significantly different compared to ISO group $(\mathrm{P}<0.05)$.

Many studies have reported the role of plant medicine in inhibiting the cardiotoxic effect of isoproterenol ${ }^{(14-16)}$ described that pretreatment with Punica granatum extract can reduce the cardiotoxic biomarker and has a lesser degree of cellular infiltration. Yousefi et al. stated the antioxidant activity might play a role in cardioprotective effect ${ }^{(15)}$. As $S$. arvensis extract has an antioxidant activity ${ }^{(6)}$, therefore it can explain its cardioprotective effect.

This study implies a pharmacological knowledge of a $S$. arvensis extract for cardioprotective effects. The mechanism of action of $S$. arvensis extract as a cardioprotective can be explored further. The limitation of this study is that the cardioprotective effect of $S$. arvensis extract was only determined by measuring the cardiac biomarker. It is important to do heart histopatology to observe its effect on preventing heart tissue damage due to isoproterenol administration. Moreover, this study was done on rat; it is unknown whether the results can be extrapolated to humans.

\section{CONCLUSION}

Sonchus arvensis L. extract ameliorates cardiotoxic effects of isoproterenol, therefore it has a potential to be developed as cardioprotective drug.

\section{ACKNOWLEDGEMENTS}

This study was supported by the Research, Community Service, and Innovation Programme 2017, Bandung Institute of Technology (P3MI ITB 2017), Indonesia.

\section{REFERENCES}

1. World Health Organization. Non communicable disease in the South East Asia Region: situation and response 2011. India: WHO Regional Office for Southeast Asia; 2011. 35.

2. Grimm D, Elsner D, Schunkert H, Pfeifer M, Griese D, Bruckschlegel G, et al. Development of heart failure following isoproterenol administration in the rat: role of the renin-angiotensin system. Cardiovasc Res. 1998. 37:91-100.

3. Boluyt MO, Long X, Eschenhagen T, Mende U, Schmitz W, Crow MT, et al. Isoproterenol infusion alteration in expression of hypertropy-associated genes in rat heart. Am J Physiol. 1995.269:638-47.

4. Sagor MAT, Tabassum N, Potol MA, Alam MA. Xanthine oxidase inhibitor, allopurinol, prevented oxidative stress, fibrosis, and myocardial damage in isoproterenol induced aged rats. Oxid Med Cell Longev. 2015:478039.

5. Bramwell D, Dakshini KMM. Luteolin 7-O glucoside and hydroxycoumarins in canary island Sonchus species. Phytochemistry. 1971.10:2245-6.

6. Khan RA. Evaluation of flavonoids and diverse antioxidant activities of Sonchus arvensis. Chem Cent J. 2012.6:126.

7. Larson AJ, Symons JD, Jalili T. Therapeutic potential of quercetin to decrease blood pressure: review of efficacy and mechanisms. Adv Nutr. 2012.3(1):39-46.

8. Dipiro TJ, Talbert RL, Yee GC, Matzke GR, Wells BG, Posey M. Pharmacotherapy: A pathophysiologic approach, $9^{\text {th }}$ ed. New York: Robert L. Talbert; McGraw Hill Education; 2014.291-8. 
9. Dhalla NS, Temsah RM, Netticadan T. Role of oxidative stress in cardiovascular disease. J Hypertens. 2000.18(6):655-73.

10. Mythili S, Malathi N. Diagnostic markers of acute myocardial infarction. Biomed Rep. 2015. 3(6):743-8.

11. Feron O. Pyruvate into lactate and back: from the Warburg effect to symbiotic energy fuel exchange in cancer cells. Radiother Oncol. 2009.92(3):329-33.

12. Karlsson M, Wiberg-Itzel E, Chakkarapani E, Blennow M, Winbladh B, Thoresen M. Lactate dehydrogenase predicts hypoxic ischaemic encephalopathy in newborn infants: a preliminary study. Acta Paediatr. 2010.99(8):1139-44.

13. Kato GJ, McGowan V, Machado RF, Little JA, Taylor $\mathrm{J}$ 6th, Morris CR, et al. Lactate dehydrogenase as a biomarker of hemolysis-associated nitric oxide resistance, priapism, leg ulceration, pulmonary hypertension, and death in patients with sickle cell disease. Blood. 2006.107(6):2279-85.

14. Eigentler TK, Figl A, Krex D, Mohr P, Mauch C, Rass K, et al. Number of metastases, serum lactate dehydrogenase level, and type of treatment are prognostic factors in patients with brain metastases of malignant melanoma. Cancer. 2011.117(8):16971703.

15. Mohan M, Patankar P, Ghadi P, Kasture S. Cardioprotective potential of Punica granatum extract in isoproterenol-induced myocardial infarction in Wistar rats. J Pharmacol Pharmacother. 2010.1(1):327.

16. Sivakumar V, Rajeshkumar S. Screening of cardioprotective effect of Terminalia arjuna Linn. bark in isoproterenol-induced myocardial infarction in experimental animals. Int J Pharm Sci Res. 2014.5(6):262-8.

17. Patel KJ, Panchasara AK, Barvaliya MJ, Purohit BM, Baxi SN, Vadgama VK, et al. Evaluation of cardioprotective effect of aqueous extract of Garcinia indica Linn. fruit rinds on isoprenaline-induced myocardial injury in Wistar albino rats. Res Pharm Sci. 2015.10(5):388-96.

18. Yousefi K, Soraya H, Fathiazad F, Khorrami A, Hamedeyazdan S, Maleki-Dizaji N, et al. Cardioprotective effect of methanolic extract of Marrubium vulgare L. on isoproterenol-induced acute myocardial infarction in rats. Indian J Exp Biol. 2013.51(8):653-60. 